\author{
BENCE Erika \\ Újvidéki Egyetem, Bölcsészettudományi Kar \\ Magyar Nyelv és Irodalom Tanszék \\ Újvidék, Szerbia \\ erika.bence@fff.uns.ac.r
}

\title{
MI TÖRTÉNT A JUGOSZLÁVIAI/VAJDASÁGI MAGYAR IRODALOMBAN 1918-BAN?
}

\author{
What happened in hungarian literature \\ in Yugoslavia/Vojvodina in 1918? \\ Šta se dogodilo u mađarskoj književnosti \\ u Jugoslaviji/Vojvodini 1918. godine?
}

\begin{abstract}
A kutatás a vajdasági magyar irodalomtörténeti diskurzus egyik legfontosabb, mindmáig érvényesnek tekintett alapelvét, az 1918-as kezdetekről alkotott axiómát járja körül. Az eredmények értelmezése és interpretációja számba veszi azokat az ideológiai behatásokat, történeti-poétikai hagyományokat és irodalomtudományi szemléleteket, amelyek nyomán és hatására az említett kanonizációs eljárások (a vajdasági magyar irodalomtörténeti szintézis, a jugoszláviai, majd a vajdasági magyar irodalmi lexikon létrehozása, könyvtörténetek és bibliográfiák megjelenése) a jugoszláviai/vajdasági magyar irodalom kezdeteit egy politikai konstrukció, az SZHSZ Királyság létrejöttének időpontjával kapcsolták össze. A dolgozat bemutatja, hogy az irodalom alakulástörténetéről szóló modern felfogások milyen értelemben helyezték hatályon kívülre a jelölt történeti elképzeléseket meghatározó pozitivista és szubsztancialista módszereket, módosítva/rekonstruálva ezáltal a jugoszláviai/ vajdasági magyar irodalom létformájáról alkotott összképet. Mindeközben az értelmezés megörzi a történeti hagyományok (például Bori Imre irodalomtörténeti víziója) kánonalkotó, elöremutató és maradandó értékeit.

Kulcsszavak: 1918, jugoszláviai/vajdasági magyar irodalom, SZHSZ Királyság, Szentelekykultusz, Tarkó János
\end{abstract}




\section{Bevezetö: a „kezdet” kérdése}

A „kezdet” kérdése a jugoszláviai magyar irodalom alakulástörténetében többes alakzatot (több kezdetet) generál, és természetének megfelelően aktivizálja a kultuszteremtő szemléleteket:

Szenteleky Kornél tevékenysége a vajdasági magyar irodalom kezdőpontjaként szituálódik, méghozzá oly módon, hogy az „első időkön” belül több jelentős kezdet-alakzat, elsőként állítható mozzanat (folyóiratvállalkozás, az „,́rói rend” megteremtése, szellemi mozgalomteremtés, többirányú irodalmi kapcsolatteremtés, antológiaszerkesztés, kultuszalapítás stb.) is létesül (Faragó 2004, 78).

Faragó Kornélia a „kezdet-kultusz” Szenteleky Kornél személyével és munkásságával összefüggő létesülése kapcsán a kettő, ,az új históriai kezdetek” és az „irodalmi élet kezdetei” különállóságára mutat rá, „Szenteleky ugyanis kultikusan jól körülírható [...] késéssel lépett a teremtés történetébe, amelynek kardinális pontja a közösség új irodalmi-kulturális mikrokozmoszának megkreálása volt" (Faragó 2004, 78).

\section{Bori Imre koncepciója}

A térségi, azaz a jugoszláviai (később: vajdasági) magyar irodalom alakulástörténetére vonatkozó legjelentősebb koncepció Bori Imre (1929-2004) nevéhez füződik. A jugoszláviai magyar irodalom története címü összefoglaló munkájának 1968-tól 1998-ig megjelentetett változatai és kiadásai ${ }^{1}$, sőt, 2007-es posztumusz megjelentetése ${ }^{2}$ is arról tanúskodik, hogy az irodalomtörténész az összefüggésrendszert rugalmas imperativusként, „történő” eseményként kezelte, s nemcsak az aktuális jelen szempontjából, amelynek értelmében folyamatosan új jelenségek tevődnek hozzá a nagytörténethez, hanem a rálátási távlat módosulásai és a szemléletváltások révén keletkezett újraértelmezések miatt is.

\footnotetext{
${ }^{1}$ A jugoszláviai magyar irodalom története 1918-1945 (1968), Irodalmunk évszázadai: A jugoszláviai magyar irodalom rövid története $(1975,1982)$, A jugoszláviai magyar irodalom rövid története (1983), A jugoszláviai magyar irodalom története (1998, reprintelve: 1999).

${ }^{2}$ A 2007-es kiadás szerkesztői jegyzetében olvashatni: „....hogy maga Bori Imre is tervezte könyvének további bővítését (az immár ötödik kiadást), bizonyítja, hogy az említett munkapéldányban rengeteg újságkivágatot, tehát információs anyagot találtunk, könyvkritikákat, méltatásokat, eseményekre szóló meghívókat, díjkiosztási tudósításokat, 1999-től évi könyvjegyzékeket, gyászjelentéseket, nekrológokat...” (Bordás 2007, 399).
} 
A jugoszláviai magyar irodalom történetét a regionális, azaz a térségben keletkezett magyar irodalom „elötörténeté”-nek fejezeteivel egészíti ki, illetve ebben a kontextusban oldja fel a „semmiből keletkezés” életszerütlen elképzelését. 1918 őszének eseményeit „történelmi és társadalmi-politikai változások"-nak nevezi, amelyek nagy szerepet játszottak a ,jugoszláviai magyar irodalom megszületésében", mert:

az Osztrák-Magyar Monarchia felbomlott, új nemzeti államok keletkeztek, közöttük Jugoszlávia is, ennek következtében vidékeink szellemi élete olyan új feltételek közé került, amelyek önállóságukat biztosították, a békeszerződések kijelölte határok pedig a jugoszláviai magyar irodalom határait is jelentették, meghatározva azokat a területeket, amelyeken a magyar szellemi élet Jugoszláviában kifejtheti hatását, ahonnan olvasóközönségét és tehetséges alkotóit várhatja (Bori 2007, 69).

Amíg a regionalitás topográfi i jellemzői könnyebben kivehetőnek bizonyultak a térség irodalmában, mi több, irodalomszociológiai változások hatására már jóval 1918 elött megmutatkoztak (negatív értelmü) jelei, például úgy, hogy a „Budapesten összpontosuló tőke a szellemi életben is éreztette hatását. A vidéki szellemi központok elvesztették jelentőségüket, a vidék a szellemi javakat immár nem teremtette, csupán fogyasztotta, és aki érvényesülni akart, annak Budapestre kellett mennie" (Bori 2007, 69), addig az időbeli határainak kijelölése nagyon is sok szempontú és rugalmas imperativust igényel; a „kezdet” határvonalának képlékenységét, a dátum pontos meghatározásának lehetetlenségét feltételezi. Történik ez azért, mert az irodalom létformája, miként a modern irodalomtudomány - Bahtyintól Jausson át Gadamerig - hatásosan és precízen tisztázta ezeket a kérdéseket: jelenségek bonyolult hálózatát jelenti; a különböző pozitivista és szubsztancialista szempontok érvényességét cáfolandó: a fontos láncszemek, összetevők és relációk (például befogadói elvárások és visszacsatolások) hiányában nem müködik. Erre a jelenségre vonatkozik Bori megállapítása:

Ha íróink gyorsan felismerték a valóságos helyzetet, és ahhoz igyekeztek alkalmazkodni, legalább törekvéseikben a jugoszláviai magyar szellemi élet teljesebbé tételének szükségességét képviselték, a közönség a lejátszódott változásokat alig vette tudomásul, úgy viselkedett, mint a háború elött, az értékes irodalmat éppen úgy Budapestről várta, mint a szórakoztatót, amelynek nagy keletje volt már akkoriban is (Bori 2007, 70).

Az irodalomtörténész tehát el tudja képzelni egy politikai konstrukció (SzerbHorvát-Szlovén Királyság) és egy irodalmi szerveződés (jugoszláviai magyar 
irodalom) térbeli koordinátáinak egybeesését, de már a következő bekezdésben leszögezi, hogy „ezek a változások”, azaz a jugoszláviai magyar irodalom mint szellemi konstrukció létrejötte - noha ,az irodalmi élet” (és nem a ,jugoszláviai magyar" irodalmi élet) nyomban az események után ,jelt adott magáról” - nem játszódtak le „megrázkódtatások nélkül”, mi több, ,az öneszmélés folyamata éveken át tartott”, s csak ezek után, e folyamatok ,végeredményeként [...] tisztázódtak a jugoszláviai magyar irodalom fogalma és jellege körüli kérdések" (Bori 2007, 69). Nagyon óvatosan fogalmaz, amikor ezeknek az írói helyzetfelismeréseknek az időpontját próbálja meg behatárolni, sokkalta inkább évtizedes folyamatokkal és polémiákkal („Van-e vajdasági magyar irodalom?”), mintsem valamely konkrét kezdeményezéssel, vagy egyetlen mü megjelenésével hozza összefüggésbe a jugoszláviai magyar irodalom konstituálódásának szituációját (Bori 2007, 70). A hírlapokhoz, újságokhoz kötődő első fontosabb megnyilvánulásokat, kísérleteket és jeladásokat is csak az 1920-as évek elejére teszi. Ennek perspektívájából lett kanonizált alakulástörténeti tény, miszerint a jugoszláviai magyar irodalom első, távlati koncepciót, manifesztatív szándékot és befogadói elvárásokat is feltételező, illetve tartalmazó megnyilatkozása a Radó Imre és Dettre János szerkesztette, 1924-ben napvilágot látott Vajdasági magyar irók almanachja I. volt (Bori 2007, 70).

Bori Imrének a jugoszláviai/vajdasági magyar irodalom létesüléséről alkotott víziója megegyező szempontokat és aspektusokat vet fel a bevezetőben kiemelt kezdet-alakzatokkal, illetve azokkal az elképzelésekkel, amelyek a jugoszláviai/vajdasági magyar irodalmi élet kezdeteit a magányos teremtők, irodalomalkotók (Szenteleky Kornél, Draskóczy Ede) felléptével hozzák összefüggésbe, különválasztva ezáltal a politikai és historikus kezdeteket az irodalmi korszakhatárok és kezdetek alakzataitól.

\section{Praktikus szempont és legitimációs igyekezet}

A mủvelődéstörténeti megközelítések a jugoszláviai/vajdasági magyar irodalom létesülését konkrét eseménnyel, a Szerb-Horvát-Szlovén Királyság megalakulásával hozzák összefüggésbe, és arra keresik a választ, hogy „melyik volt a jugoszláviai magyar irodalom első könyve", ugyanakkor az ily módon megállapított ,jeladás”-t (Csáky S. 1988, 18), illetve „öneszmélés”-t (Németh 2018, 131) nem magyarázzák a szuverén - azaz belső alakulástörvényeknek engedelmeskedő, történeti-poétikai események mentén létrejött - rendszer (egy irodalom létformája) szempontjából. „1918-ban új szellemi élet kezdett kialakulni Jugoszláviában és Vajdaságban” (Csáky S. 1988, 16) - olvashat- 
juk a könyvtörténeti monográfiában, melynek - a bevezető tanúsága szerint „célja a könyv és az irodalom kapcsolatának megvilágítása” (Csáky S. 1988, 8). Ugyanakkor a valóban felkutatott és megállapított müvelődéstörténeti események (a könyvkiadásra és a sajtóra vonatkozó törvények és rendeletek, az intézményes könyvkiadás helyzete és kezdeményezései, az első napvilágot látott könyvek etc.) számbavétele mellett adós marad azoknak az új karakterisztikáknak és konstruktív elemeknek a kifejtésével és értelmezésével, amelyek a jugoszláviai magyar irodalmat alkotó új szellemiséget jelentik vagy jelentenék, s amelyeknek megjelenésével és müködésével együtthatóan új irodalom „létesül”.

Ha gyüjtésünk hiányos is, s ha az 1918-ban megjelent múveket nem soroljuk is be az újonnan születendő vajdasági magyar irodalom kiemelkedő alkotásai közé (mivel valószínűleg előbb keletkeztek), az 1919-ben kiadottakat viszont már mindenképpen annak kell tekintenünk. Irodalmi értéküket nem mérlegelve, pusztán megjelenésüket véve alapul, úgy véljük, hogy Boschan Sándor A cigányasszony c. munkája, esetleg Borsodi Lajos Fenség c. müve volt az első irodalmi alkotás, amely 1918 után jött létre Vajdaságban. (Ez utóbbin nincs évjelzet feltüntetve, mi 1920ra tettük a megjelenési évét.) (Csáky S. 1988, 18.)

A megállapítás amellett, hogy önellentmondást is tartalmaz, azt sugallja, hogy valamely irodalmi reprezentációnak 1918-ban voltak „kiemelkedő” alkotásai, azonban, mert nem az adminisztratív/politikai konstrukció, a SzerbHorvát-Szlovén Királyság megalakulásának dátuma (1918) után keletkeztek, nem tekinthetők a vele (vagyis a politikai létesítménnyel) együtt megjelenő „új szellemiség" (a jugoszláviai magyar irodalom) részének, ellentétben azokkal, amelyek 1919-ben láttak napvilágot, még akkor is, ha ez utóbbiak ,irodalmi értéke" kétséges lenne, vagy elmaradna az előbbiek színvonalától. A közlés nyilvánvalóan fontos és pontos bibliográfiai tételeket tartalmaz, de semmiképp sem magyarázza a vele összefüggésbe hozott (a vele, azaz a könyvkiadás történetével, dokumentumanyagával felcserélhető történetként kezelt) szellemi konstrukció létrejöttének körülményeit, nem támasztják alá azt, hogy ez az új irodalmat teremtő szellemiség 1918-ban már létezett, s hogy ezáltal a jugoszláviai magyar irodalom története innen veszi kezdetét ${ }^{3}$, miközben magáról a jelenség irodalmi és esztétikai lényegéről nem árul el sem tényeket, sem kutatási előfeltevéseket, s ezeknek bizonyítását és kifejtését sem tartalmazza.

\footnotetext{
${ }^{3}$ A kérdéssel foglalkozó kutatások még: Bence 2015a; Bence 2017; Bence 2018.
} 
A vitatott könyvtörténeti adatbázis és bevezető tanulmánya a múlt század nyolcvanas éveiben, egy ma már erősen vitatható ideológiai irányvonal mentén jött létre, miközben az alapját képezö irodalomtörténeti koncepció, Bori Imrének a jugoszláviai magyar irodalomról alkotott elképzelései (ezt az új kiadások és recepciójuk változásai mutatják) is módosultak. Épp ezért - a könyvtörténet újragondolásának hiánya és a Bori-koncepciónak a szerző halálával történt véglegessé, mozdíthatatlanná válása miatt - nem képezhet kizárólagos hivatkozási alapot a jugoszláviai magyar kisebbségi irodalmi reprezentáció jelenségeinek 21. századi értelmezéseihez. Azok az események, amelyeket felsorol (SZHSZ Királyság létrejötte, Obznana, Vidovdani alkotmány etc.) jogi/politikai értelemben befolyásolták a vajdasági magyar sajtó és könyv megjelenési, illetve kiadási lehetőségeit, ugyanakkor nem következik belőlük automatikusan a térség korábbi irodalmát hatályon kívül helyező „új szellemiség” értelmezése (Bence 2018). Az 1918-as „kezdetről” alkotott elképzelést nem támasztja alá, legfeljebb praktikus szempontként funkcionál kézi- és tankönyvek írásához és semmiképp sem jelenthető ki nyomvonalán haladva, hogy ,az első fontos irodalmi jeladás, egyben a kisebbségi vajdasági magyar irodalom első terméke 1919 februárjában Tarkó János Amíg a nagy vihar tombolt... címủ regénye volt" (Németh 2018, 131).

\section{A Tarkó-rejtély és feloldása}

A jugoszláviai magyar irodalom története 2007-es, posztumusz kiadásának szerkesztői jegyzete (Bordás 2007, 399) említést tesz arról, hogy a szintézis ötödik kiadásának tervezetében, amit az irodalomtörténész özvegye bocsátott a kiadó rendelkezésére, a számos újságkivágat és információs anyag között szerepel egy müvelődéstörténeti jegyzet Tarkó János - a jegyzet szerzője által „a vajdasági magyar irodalom első köteté”-nek tartott - könyvéröl. A térség kulturális és irodalmi közéletét, kiadástörténetét feldolgozó bibliográfiai füzetek (Ispánovics Csapó 2009) segítségével kideríthető, hogy Németh Ferencnek (Németh 2001) a Magyar Szó napilap Kilátó címü mellékletében megjelent cikkéről van szó. A szerző ugyane témában jelentetett meg hosszabb publi-

\footnotetext{
${ }^{4}$ „A társadalmi-történelmi fordulópontokhoz kötődő irodalomtörténeti, irodalomértési hagyomány korszakolása művészeti, irodalmi szempontból nem a legszerencsésebb, inkább egy praktikus, a kézikönyvírás gyakorlata által életre hívott, fenntartott hagyomány eredménye. [...] A kulturális, irodalmi öntudatra ébredés a társadalmi-politikai traumán túl paradigmaváltásnak is tekinthető, s mint ilyen nem a semmiből jött, előjelei, készülődései már az 1918 elötti időszakban is jelen vannak" (Ispánovics Csapó 2011, 7).
} 
kációt a Tanulmányok 2014/1-es számában, amelyben a Tarkó-regényről az első világháború kitörése kapcsán, mint a vajdasági magyar háborús regények egyik korai ${ }^{5}$ megjelenéséról és változatáról esik szó. A Tarkó-regény emellett tárgyát képezi egy 2018-ban napvilágot látott tanulmánynak is (Németh 2018), amelyben a térségi (értsd: jugoszláviai magyar) „kisebbségi, irodalmi öneszmélés” első ,jeladása"-ként reprezentálódik (Németh 2018, 131). A terminus technicus eredetéből következik, hogy a kiindulási alap itt is a Csáky S.-féle 1988-as kiadástörténeti bibliográfia és Bori Imre lezárult irodalomtörténete, amelynek 1998-as kiadására hivatkozik a cikkíró.

A Gerold László (1940-2016) által írt és szerkesztett vajdasági irodalmi lexikon (Gerold 2016) előszavának bibliográfiai adatai között szerepel ugyan Tarkó János Amíg a nagy vihar tombolt ... címú, 1919-ben napvilágot látott regénye, azonban a lexikográfus kihagyja a szócikkek sorából, mivel állítása szerint szerzőjének életéröl „szinte semmit sem sikerült kideríteni” (Gerold 2016, VII).

A problémát körüljáró történeti-poétikai és komparatív vizsgálatok (Bence 2015a, Bence-Kocsis 2019, Bence-Ispánovics Csapó 2020) ugyanakkor arra az eredményre vezettek, hogy mindkét út hibás, vagyis az irodalmi vizsgálatokat nélkülözö, csak a kiadástörténeti adatokra és a tartalmi megfeleltetésekre támaszkodó bemutatás éppúgy téves eredményekhez vezet, mint az, ahogy a lexikoníró eltekintett a kutatások kiterjesztésétől, a lehetséges források számbavételétől. ${ }^{6} \mathrm{Az}$ előző álláspontra jellemző, hogy felhasználja a korabeli sajtó híranyagát az adott időszak, az első világháborút követő politikai és jogi átrendeződés időszakában jelentkező folytatási (és nem okvetlen újraértelmezési) kísérletekről, s egy ilyen (de kulturális és irodalmi argumentumokkal alá nem támasztott) kontextusba helyezi a Tarkó-regény megjelenését. Például felhasznál

\footnotetext{
${ }^{5}$ Az első világháború történéseit tematizáló regények domináns, második vonulata mind az európai, mind a magyar irodalomban, így a ,jugoszláviai magyar irodalom"-nak nevezett reprezentáció keretein belül is a háború lezárulta után egy-másfél évtizeddel később konstituálódik, vagyis a történések hiteles (elfogultságoktól mentes és konzekvens) elbeszélését lehetővé tevő rálátási távlat kialakulását követően, hozzávetőlegesen 1927-től kezdődően jelennek meg poétikai és esztétikai szempontból is erőteljes, jelentős alkotások, többek között Markovits Rodion Szibériai garnizon (1928) és Aranyvonat (1929), Darvas Gábor Mindent meggondoltam és mindent megfontoltam (1930), Munk Artúr A nagy káder (1930) és A hinterland (1933) című regényei. Létezik ugyan néhány korábbi kísérlet is, közülük kétségkívül Jaroslav Hašek Švejkje (1923) a legjelentősebb és világhírüvé lett alkotás. A jelölt hivatkozások azt sugallják, mintha Tarkó János Amíg a nagy vihar tombolt... címü regénye is ebbe a sorba tartozna, ám a feltételezés csak addig állja meg a helyét, amíg csupán kiadástörténeti adatokat veszünk figyelembe A regény történeti-poétikai és összevetö vizsgálata egészen más képet mutat (Bence 2015a).

${ }^{6}$ A kérdéssel részletesen foglalkozó tanulmány: Bence 2018. http://www.naputonline. hu/2018/01/07/bence-erika-vajdasági-magyar-irodalmi-lexikon-1918-2014/
} 
„asztaltársaságok"-ról és a körükben jelentkező mükedvelő kezdeményezésekröl szóló sajtóhíreket, ám ezekből semmilyen, a jugoszláviai magyar irodalom „új szellemiség"-ére vonatkozó konkrétumra, esetleges identifikációs vagy legitimációs kísérletre nem derül fény, miközben az asztaltársaságok, a hírlapírás és az irodalmi élet, mindenekelött az anekdotikus (bricolage) alapú regényírás összefüggései, együtthatása már a 19. század közepétől, mindenekelőtt Jókai Mór, majd később Mikszáth Kálmán mủvei keletkezéstörténete révén ismert jelenség az irodalomtörténet-írásban (Rózsafalvi 1998, 137-150; Hajdu 2001, 219-242; Bence 2012, 54).

Az ,első jeladás”-ként megnevezett (Németh 2001, Németh 2018), más kontextusban a „Nagy Háború ismeretlen regénye”-ként tárgyalt (Németh 2014) Tarkó-mủ a fentiekben jelölt (Bence 2015a) és a jelen vizsgálat tükrében is egészen más jelentéskörben vált láthatóvá: se nem „kisebbségi” magyar, s mert az első világháború eseményei legnagyobbrészt kulisszaként vannak jelen világában, még csak nem is tipikus háborús regény; Jules Verne-típusú tudományos-fantasztikus kalandregény (Bence 2015a).

Mind a lexikográfiai, mind a művelődéstörténeti eredetü törekvések - a róla begyüjthető viszonylag kevés adat, valamint a „legendásítás” szándéka (megfigyelhető például ennek retorikája: „egy tanító bevonul az irodalomba”, Németh 2001, 13) - nyomán hiányos kép alakult ki Tarkó János életmüvéről. Az ,egyéni felfedezés”-ig (Németh 2001) ismeretlenként aposztrofálódó mü új irányadóként való megjelenítése ugyanis első látszatra tényleg átalakíthatja a jugoszláviai/vajdasági magyar irodalom alakulástörténetéről alkotott képet ('́gy Bori Imre fentiekben vázolt vízióját), és új - az európai tendenciáktól eltérő - jelentéssel gazdagíthatja a térségi első világháborús magyar regények történeti sorát. Vitathatatlan, hogy jelen kutatás is, amelynek ez a tanulmány csak egy szegmensét ismerteti, eleinte ezen a nyomvonalon indult el, s felvetette annak lehetőségét is, hogy a vajdasági kisebbségi irodalmi reprezentáció nemcsak a „magányos nagyságok” alakjában felismert irodalomteremtők (például Szenteleky Kornél) tevékenysége és az Isola Bella (1931) felől olvasható, hanem létezik egy sokkal korábbi kezdete (Bence 2017; Bence 2018). A kiterjedtebb és a kontextualizált vizsgálatok azonban ezeket a hipotéziseket nem igazolták, mi több, arra mutattak rá, hogy a megjelenés „elsőség”-e önmagában csak adatbázisokban felhasználható adat, míg a puszta tartalomvizsgálat - mivel hermeneutikai értelemben az irodalmi mủ nem önmagában álló jelenség - irodalom- vagy alakulástörténeti szempontból nem releváns módszer (Bence 2015a; Bence 2017; Bence 2017a; Bence 2018a; Bence-Kocsis 2019; Bence-Ispánovics Csapó 2020). 
Már relatíve kis volumenü bibliográfiai és adatbázis-kutatás nyomán láthatóvá válik, hogy Tarkó János Amíg a nagy vihar tombolt... címü regénye egyáltalán nem volt annyira ismeretlen, vagy „eltünt” adat a recepciótörténeti vagy bibliográfiai adatbázisokból, mint ahogy azt a mủvelődéstörténeti publikációk bemutatják: az OSZK katalógusában ${ }^{7}$, olvasóköri könyvlistán ${ }^{8}$ (1935), valamint Gulyás Pál ${ }^{9}$ kiadástörténeti bibliográfiáj ban is szerepel. Viszonylagos ismeretlensége a korszak híressé, sőt, világhírüvé lett háborús regényeinek (például Markovits Rodion Szibériai garnizon, Kuncz Aladár Fekete kolostor vagy Munk Artúr A nagy káder címü alkotásainak) elhomályosító hatásából/híréből következik. Mi több, megkockáztathatjuk azt az állítást is, hogy a rendelkezésre álló egynéhány életrajzi adat alapján - figyelembe véve, hogy a jugoszláviai/ vajdasági irodalmi lexikon mindkét kiadásában vannak ennél szerényebb dokumentációra támaszkodó cikkek is (Bence 2018) - a róla szóló lexikonszócikk is megírható lett volna. Például korábban is tudni lehetett Tarkóról, hogy 1905 és 1920 között (legkésőbb 1922-ig) általános műveltségi tárgyakat oktatott a nagybecskereki Központi Állami Elemi Iskolában és az Iparostanonc Iskolában (Németh 2001, 13), hogy verseit és elbeszéléseit fóvárosi és vidéki lapokban publikálta (1902-ből és 1912-ből vannak vonatkozó adatok), pedagógusként és közszereplőként a térségi müvelődési életben történő szerepvállalásának is vannak dokumentált nyomai, illetve 1922 után magyarországi körökben tankönyvíróként tünik fel (Németh 2014, 103-104). De az alakulás- és müfajtörténeti szempontú vizsgálatok számára legfontosabb kiindulópontot és vizsgálati anyagot maga az elérhetô, olvasható és vizsgálható regény jelenti.

Tarkó János alakját és életmủvét azért is lengi be valamiféle (generált) titokzatosság, mert az öt érintő gyér kutatások (Németh 2001, Németh 2014, Németh 2018) 1922-től kezdődően már nem találtak rá vonatkozó adatot sem a jugoszláviai/vajdasági magyar, sem a magyarországi irodalomban való jelenlétét illetően, ami egy tudatos irodalomteremtő habitus (mủve a „vajdasági magyar irodalom első regénye", Németh 2014, 106; Németh 2018, 131) szempontjából érthetetlen jelenség lenne, ezért szinte adta magát az a magyarázat, miszerint 1919-ben, a térséget átalakító politikai változásokkal (a Szerb-Horvát-Szlovén Királyság megalakulásával) szinte azonos időben megjelent ugyan az új iroda-

\footnotetext{
${ }^{7}$ SZK Katalógus. é. n. http://nektar.oszk.hu/en/manifestation/3122099 (2020. nov. 4.)

${ }^{8}$ Az ormospusztai munkások olvasókörének könyvjegyzéke. 1935. Miskolc: Swarcz Soma Könyvnyomdája, 54. http://mek.oszk.hu/12000/12047/12047.pdf (2020. nov. 4.)

${ }^{9}$ Gulyás Pál. é. n. Magyar írók élete és munkái. Cédulatár. 18101. Téka http://gulyaspal.mtak. hu(2020. nov. 4.)
} 
lomalkotói gesztus (az „új szellemiség”), de valamiért már megjelenése pillanatában véget is ért, csírájában fojtódott el; szerzője soha többé nem szólt bele a jugoszláviai/vajdasági magyar irodalom alakulástörténetébe, elhallgatott, eltünt vagy - feltételezhető volt, hiszen nem rendelkeztünk konkrét életrajzi adatokkal róla - elhunyt, minek következtében Szenteleky Kornél és Draskóczy Ede (illetve más szervezők, például Dettre János, Radó Imre etc.) a 20-as évek második felében az egyszer Tarkó által már „elindított” jugoszláviai magyar irodalmat „alapítják újra”. ${ }^{10}$

Időközben azonban fény derült Tarkó János élete és pályája 1922 utáni alakulásának történetére is. ${ }^{11} \mathrm{Az}$ Amíg a nagy vihar tombolt ... címü regény szerzője, müvének megjelenését követően még több mint hat évtizedet élt és dolgozott; 1981-ben, százéves korában halt meg a pesthidegkúti idősek otthonában. Selmecbányai származású, 1967-ben elhunyt feleségével egy sírboltban nyugszik Ugodon. A Török András (1949) veszprémi nyugalmazott erdömérnök által rendelkezésünkre bocsátott adatok - természetszerüen - további verifik ciót és kutatást igényelnek, de már most fontos mozzanatokkal és jelentésekkel módosították az életmüvéről alkotott hipotéziseket. Megfontolandó tény e szempontból, hogy akinek tevékenységéhez a jugoszláviai/vajdasági magyar irodalom kezdeteit, „öneszmélés”-ét, az „új szellemiség”-ének első ,jeladás”-át kapcsoljuk, Bori Imre jugoszláviai magyar irodalomtörténetének első kiadásait $(1968,1975)$ követően is még több mint egy, illetve fél évtizedet tevékenyen élt, olvasott és dolgozott, mégsem érezte szükségét annak, hogy az említett „kezdetek"-ról alkotott képet saját tényismerete és részvétele nyomán módosítsa. Adatközlőnk e kívülállásra két lehetséges magyarázatot is adott. Az egyik Tarkó János polihisztorszerü magatartásából következik, vagyis abból az attitüdből, melynek értelmében nem csak, illetve nem elsősorban irodalmárnak, inkább természettudósnak tartotta magát, a másik viszont, hogy teljesen elhatárolódott (ezért is távozott Nagybecskerekrő' ${ }^{12}$ ) a trianoni békeszerződés nyomán létesült

\footnotetext{
${ }^{10}$ A szóhasználat egy, a magyar regény alakulástörténetét értelmező tanulmányra vezethető vissza. Lásd Márton 1998.

${ }^{11} 2019$ októberében a tanulmány íróját telefonon kereste meg Török András (1949) nyugalmazott veszprémi erdőmérnök, aki Tarkó János és családja ugodi főbérlőjének gyermeke, a Tarkó János életművére vonatkozó kutatásokra a folyóirat-publikációk elektronikus kiadásai révén figyelt fel, és számos életrajzi, szemléleti és recepciótörténeti adattal szolgált az életmü alakulását illetően.

${ }^{12}$ Adatközlőnk, Török András szerint Tarkó János Nagybecskereken született, s valószínü, hogy az SZHSZ Királyságban kötelezővé vált állami szerb nyelvvizsga miatt hagyta el az országot. Ugyanakkor addig, amíg erre vonatkozóan nincsenek konkrét dokumentumaink (például keresztlevél etc.), ezeket nem kezelhetjük bizonyított adatokként.
} 
új politikai és szellemi konstrukcióktól, nem fogadta el azokat: a jugoszláviai/ vajdasági magyar irodalom létjogosultságát is tagadta. Nem volt vajdasági és föleg nem ,jugoszláviai magyar” identitása.

Az Amíg a nagy vihar tombolt... címủ regényt azonkívül, hogy Nagybecskereken ${ }^{13}$ jelent meg, semmilyen szuverén, az irodalom és az irodalmi mü létformájából vagy müködéséből következő mozzanat nem kapcsolja a jelölt irodalmi reprezentációhoz. Ezt a mü poétikai elemzése: műfaji, komparatív és szövegvizsgálata is alátámasztja, s ennek bizonyításához - a mü belsö struktúrája és jelentéshordozása szempontjából egyébként is mellőzhető - életrajzi adatokra sincs szükségünk.

Azzal a megállapítással - ha eltekintünk poétikai fogalomtárának (például: „cselekmény” a jelentés vagy jelentéshordozás/-adás helyett) korszerütlenségétől -, hogy a „húsz fejezetből álló regény cselekményével jelképesen is lezár egy történelmi korszakot mindössze néhány hónappal az első világháború befejezése után" (Németh 2014, 104), is csak részben érthetünk egyet, mert igazából nem a regény „cselekménye”, hanem az általa megjelenített, elbeszélt történelmi esemény zárja az európai társadalomtörténetnek adott korszakát, amiből még véletlenül sem következik, hogy a mü megjelenése is korszakváltó törésvagy gócpontja lenne az európai vagy a magyar irodalom alakulástörténetének.

A regényt értelmező írás (Németh 2014) egy korabeli ajánló cikkből ${ }^{14}$ idéz - meglehetősen dagályos, hiszen az jellege szerint inkább hirdetés, mintsem kritika, vagy elemzés - megállapításokat arra vonatkozóan, hogy a nemzetek sorsát megváltoztató (tehát eposzi karakterü) történelmi esemény (az első világháború története) ,sohasem lesz érdektelen [...], a nagy viharról mesélni fog az író, a festő, a tanító vagy a filmrendező" (Németh 2014, 105), ami releváns észrevétel, hiszen az első világháború mint narratíva valóban müfaji sort nyitott az európai és a magyar irodalomban is az 1920-as évek végén. A Tarkó-regény azonban nem illeszkedik a sorba, nem azért, mert jóval korábban, nyomban a háború befejeződését követően látott napvilágot, ami értelemszerüen azt jelenti, hogy már 1918 második felében elkészült, s nem is poétikai/esztétikai kvalitá-

${ }^{13}$ Számos példa bizonyíthatja mind a régi, mind a 20. századi, de a kortárs irodalomból is, hogy a kulturális identitás és az irodalmi hovatartozás nem okvetlenül ezeken a megjelenési adatokon alapul. Szenteleky Kornél Isola Bella címủ regénye először Kolozsvárott látott napvilágot 1931-ben, Majtényi Mihály Császár csatornája címủ mủve Budapesten 1943-ban, mégis mindkettőt a vajdasági magyar irodalom szerves részének tekintjük, miként az 1990-es években a Magyarországra emigrált írók (például Gion Nándor, Balázs Attila, Bozsik Péter, Fenyvesi Ottó etc.) életmúvét is.

${ }^{14}$ Anonim. 1919. Torontál, febr. 28. (Németh 2014, 105). 
sainak mibenléte miatt, hanem mert jellegét tekintve nem elsősorban háborús regény. Erről maga a mü címe is fontos argumentummal szolgál: „Amíg a Nagy Vihar tombolt..." - ,addig” történik valami, azaz az elbeszélt történet a háború elbeszélése helyett egészen más jelentés szolgálatában áll.

A jelen kutatás keretében, a Hungarológiai Közlemények 2015/2-es számában (Bence 2015a), illetve további részkutatások kimeneteként (Bence-Kocsis 2019; Bence-Ispánovics Csapó 2020) kerültek közlésre az Amíg a nagy vihar tombolt... címü Tarkó-regény történeti-poétikai és komparatív vizsgálatának eredményei, amelyben a münek a tudományos-fantasztikus irodalommal és az államutópiákkal (mindkét esetben a Jules Verne-hagyománnyal) való összefüggéseire, az adott tendenciákra történő ráíródására mutattunk rá úgy, hogy akkor még csak a regény világának belső törvényszerüségeit, müködését és jelentéshordozását elemezhettük, nem álltak rendelkezésünkre a mü keletkezéstörténetére és az írói habitusra vonatkozó adatok. ${ }^{15} \mathrm{Az}$ említett és hozzáférhető kutatásokból itt csak azokat az attribútumokat emelném ki, amelyek diskurzusba állítják, sőt cáfolják azokat a meggyőződéseket, amelyek a regényt a jugoszláviai/vajdasági magyar irodalom „első könyve”-ként, illetve háborús regényként interpretálják.

„A szerző érthető módon nem választhatott regényének hazai helyszínt, hanem a cselekményt Franciaországba helyezte, fiktív helyre, egy francia széplélek, Colbert gróf birtokára" (Németh 2014, 105) - olvashatjuk a vizsgált elemzésben. A gondolatmenet nem tér ki arra, hogy melyek azok az „érthető okok", amiért Tarkó János regényének cselekménytere egy franciaországi „fiktív hely”, viszont a mü megjelenése körülményeinek (1919 februárjának második felében látott napvilágot) kiemelése révén azt sugallja, hogy azért, mert megváltoztak létrejöttének politikai határai, azaz megalakult az SZHSZ Királyság: az íróként való megszólalás, illetve a regény léttere immár „kisebbségi” és egy új „,szellemiség” jegyében fogant (Csáky S. 1988, 16). Csakhogy a regény „,cselekménye” erre vonatkozóan semmilyen konkrétumot, sőt, utalást

15 Török András (1949) beszámolója szerint Tarkó János több diszciplínában is jeleskedett: az Amíg a nagy vihar tombolt ... mellett verseskötete is jelent meg, Heti strófák címen volt rovata egy nagybecskereki lapban (feltehetően a Torontálban), emellett tudományos kísérleteket is végzett, elsősorban a fizika területéről. A Jules Verne regényeiben ábrázoltak közül többet is bemutatott a valóságban, például a földrajzi szélesség meghatározásának csillagászati módszerét, amiről A rejtelmes sziget címü regényben olvashatni. Kedvenc területei közé a jövőkutatás (például a hologram) is hozzátartozott, továbbá zeneművet is alkotott, sakkfeladványokat írt (állítólag még fellelhetők!), és egy, a Hunnia Filmstúdióban forgatott filmben mellékszereplöként is feltünik. Ezeknek az adatoknak az ellenőrző feltárása, természetesen, még feladatként áll előttünk. 
sem tartalmaz. Csak feltételezzük, valóban az első világháború lezárultát követően, 1918 végén nyerte el végleges formáját, mivel a háború kimenetének a főhős, Colbert gróf olyan vízióját festi meg, amely jövőbe látó képességek nélkül csak konkrét hírforrások és tapasztalatok alapján volt lehetséges, viszont ezek a források ${ }^{16}$ és tapasztalatok sem tartalmaznak sem az új államalakulatra, sem az új polgári (írói) identitásra vonatkozó jelentéseket, adatokat, de még utalásokat sem. Mi több, a regény magyar származású hősének, Kovács Gyula mérnöknek habitusa és identitástudata elsősorban európai, s csak másodlagosan „nemzeti”, azaz magyar. Eltekintve az elbeszélő által a főhős beszédébe plántált „,faji mitológiá”-tól és annak valóságértékétől, amely ugyanakkor nem azonos a több évtizeddel későbbi retrográd ideológiák elképzeléseivel, a mérnök nemzeti hovatartozásának jellemzése a francia Colbert gróf szájából hangzik el, és teljesen nélkülözi az államhatárok és politikai konstrukciók meghatározta identitás karakterisztikáit:

Ezelött tíz-tizenkét évvel beutaztam egész Magyarországot. Be' minden másként van ott, mint ahogy írják. A magyar csodálatos faj. Annyi józanságot és természetességet a világ egyetlen népében sem láttam. Megjegyzem, a népről beszélek, amely valóban a faj. A müvelt francia, angol, orosz, kínai vagy japán mindegy. Kultúremberek ezek, akik a müveltség, a társadalmi szokások, és tudomány kifejezői. Ezek pedig nem faji és sajátos tulajdonságok... (Tarkó 1919, 23).

Lehetséges magyarázatot arra vonatkozóan, hogy Tarkó János miért választja regénye színteréül Franciaországot a feltételezett müfaji sorba, az első világháborús regények vonulatába tartozó művekkel történő összehasonlító vizsgálat adhat. Ezeknek az összevetéseknek az a nyilvánvaló konklúziója, hogy az Amíg a nagy vihar tombolt ... csak igen kis mértékben mutat rokonságot azokkal a regényekkel, amelyek közé a praktikus bibliográfiai vagy kézikönyvírói igyekezet sorolná, egyszerủen azért, mert az első világháború eseményei a regény fö narratívájához és jelentésalkotásához képest csak kulisszaként funkcionálnak: arra szolgálnak, hogy a háború nyújtotta borzalmakkal ellentétben a nemzetek feletti utópia mủveltségi komponensei élesebben rajzolódjanak ki előttünk.

Az elbeszélés csak egyetlen epizód erejéig vezet el konkrét háborús események színterére: amikor föld alatti búvóhelyükről, az ott kialakított, a tudomány

\footnotetext{
${ }^{16}$ A regény szereplői kiépítenek egy föld alatti csatornarendszert, amelyen eljutnak hozzájuk a korabeli újságok, hírek és irodalom, ezekből tájékozódnak a háború eseményeiről, illetve egy alkalommal néhányan a férfiak közül a harctérre is felmerészkednek tapasztalatot szerezni
} 
és a múveltség vívmányain alapuló ideális minitársadalom férfi tagjai Colbert gróf vezetésével felmennek a felszínre, hogy tájékozódjanak. Poétikai értelemben azonban erre az epizódra sem háborús jelentéstartalma, hanem a humánum erőforrásainak érzékeltetése miatt van szükség. Colberték ugyanis a harctéren ráakadnak egy súlyosan sebesült német, azaz ellenséges katonára, és az emberélet mindenek feletti tisztelete arra ösztökéli őket, hogy a lelepleződés veszélye ellenére se hagyják meghalni: magukkal viszik és megmentik életét föld alatti birodalmukban. Hogy a történetnek pozitív lehet a kimenete, abból következik, hogy Dittrich báró személyében nemcsak az ellenség katonáját mentették meg, hanem egy magasan képzett, müvelt embert, akinek világértésében a szeretet és a humánum eszménye felülírja hazafiúi és katonai kötelezettségeit. Ellentéte az utópia világában Marcassi, a gróf olasz gépésze. Azonban az ő aszociális és retrográd magatartásának sem nemzeti hovatartozása képezi alapját, hanem tanulatlansága, primitív ösztönlény mivolta.

Noha a jugoszláviai magyar irodalom létesülése szempontjából nem jelentéses mozzanat, de a Tarkó-regény müfaji és poétikai összefüggései miatt fontos megjegyezni, miszerint abban is téved a recepció, miszerint az író „fiktív helyszín”-re helyezte szintén „nem létezett” hőseit. Ugyanis a szimbólumok, utalások jelentéshordozásából egyértelmüen kideríthető, hogy Colbert gróf JeanBaptiste Colbert (1619-1683) ismert államférfi - nagy valószínúséggel fiktív - utódja ('́gy nem létezett, de elképzelhető létezése): a regény világát tekintve a tudomány és a kultúra fontosságának és a nemzetek sorsát meghatározó jelentőségének, a jövő feltételeként való láttatásának jelentésadása miatt fontos szerepeltetése, miként annak a családi hagyománynak is, amelyet képvisel. Colbert gróf birtoka a Champagne vidékén, az Aisne folyó mentén terül el: az első világháború krónikájából tudjuk, hogy a folyó mentén 1914-től 1918-ig három nagy, úgynevezett aisne-i csata is lezajlott. Tehát azok az események, amelyekről a miniköztársaság tagjai a szó szoros értelmében vett információs csatornákon keresztül érkező hírekből (egy csőrendszert építenek ki, amelyeken megbízható ismerősök információkat és hírlapokat juttatnak el hozzájuk) és a felszínre történő kilépésükkor értesülnek, ezeket az eseményeket jelentik.

Az Amíg a nagy vihar tombolt ... legtöbb hasonlóságot, analóg vonást Kuncz Aladár Fekete kolostor (1931) címü, az első világháborút tematizáló magyar regények sorába ugyancsak nehezen illeszthető regényével mutat. Kuncz művének alcíme, Feljegyzések a francia internáltságból, egyértelmüen utal arra, hogy nem frontélményeket, hanem a fogságnak egy (például Markovits Rodion vagy Munk Artúr ismert regényeihez, a hadifogoly-lét történéseihez képest) más vetületét megjelenítő regényről van szó. Egy internálótábor vilá- 
gát mutatja be előttünk, ahol a háború árnyékában, egy különös világ, egyfajta „posztmonarchikus” társadalmi tabló képződik meg előttünk, miként Tarkó János vizsgált regénye is háttérré transzformálja a világtörténelmi eseményt. A Fekete kolostor elbeszélője konkrét példával is érzékelteti ezt a kívülállást:

A marne-i csatának napjai úgyszólván észrevétlenül múltak el fejünk fölött. Perigueux népe, amely pedig déli természeténél fogva oly élénken visszhangzott minden eseményt, a háború e döntő fordulatának nem szentelt semmiféle tüntető felvonulást. Talán csak abból következtethettünk arra, hogy a németek faltörőkosa nem mért végzetes csapást a franciákra, hogy a szerencsétlen internáltaknak idegenlégióba való csábítgatása újra megkezdődött. Tovább kellett tartani a háborúnak, ha érdemes volt újra toborozni. Legalábbis a franciák így gondolkozhattak, mert mi viszont még nem tudtuk elhinni, hogy a háború két-három hónapnál tovább nyúlna (Kuncz 1931, 37).

Ugyanakkor a Kuncz-regény és keletkezéstörténetének vizsgálata (BenceIspánovics Csapó 2020) közvetett, de logikus magyarázattal szolgálhat arra vonatkozóan is, milyen ,érthetö" indítéka lehetett annak, hogy Tarkó János saját regényének teréül Franciaországot tette meg. Kuncz ugyanis úgy és azért rekedt az országban, illetve került internálótáborba, mint egy ellenséges ország polgára a háború kitörését követően, mert számos polgártársához hasonlóan olyan mértékben volt frankofil, rajongott a francia kultúráért és a korabeli múveltségért, hogy az felülírta benne a politikai hovatartozás és a háborús ellenségkép alkotta elhatárolódás szándékát, illetve az elővigyázatosságot; nem menekült el idejében az országból, mert hitt a kultúra nemzetekfelettiségében. A müveltségi tárgyakat oktató - a kezdeti összehasonlító vizsgálatokhoz képest (Bence 2015) utólag nyilvánvalóvá lett, s az adott eredményeket is megerősítő életrajzi adatokból tudjuk -, több tudományban és diszciplínában is jártas, alkotó ember, Tarkó János Jules Verne-rajongó is volt. Azt is elképzelhetjük róla, hogy a korabeli müveltségi mintáknak megfelelően maga is frankofil beállítottságú. Ezért szinte adja magát a válasz, hogy a Verne-regények (például A Fekete Indiák, Várkastély a Kárpátokban etc.) mintájára alkotott regénynek (Bence 2015a) amely a hasonló karakterü, a Jules Verne-jelenségtől sem függetleníthető Jókairegények (például A fekete gyémántok) világából is merít - Franciaország lehetett az író ízlése és választása szerinti legadekvátabb helyszíne, hiszen közvetlen környezetére nem volt jellemző az a müveltségi potenciál, amelyet a regény világa képvisel és megjelenít (csak Colbert gróf és az elbeszélő látomásában szerepel, mint lehetőség). 


\section{Összegzés}

Ha figyelm n kívül hagynám az értekezői nyelvhasználat követelményeit, akkor a címben feltett kérdésre poénszerủ választ adnék: semmi; nem is létezett.

A regény első világháborús magyar regények sorában, a Jules Vernehagyomány és a Jókai-opus összefüggésében történő vizsgálata és értelmezése ugyanakkor arra is rámutat, hogy egy bibliográfiai adat (1919-ben Nagybecskereken megjelent egy regény) önmagában nem elegendő és nem mérvadó a kiterjedt, többdimenziós és -jelentésü alakulási folyamat, egy irodalom létesülése megfejtéséhez és megértéséhez. Egy irodalmi reprezentáció létformája nem elsősorban anyagelvü mechanizmusokon alapul, mi több, az irodalom alakulás- vagy irodalomtörténeti koncepciója szempontjából az a mozzanat, hogy melyik könyv jelent meg az adott politikai kontextusban elöször, majdnem teljesen érdektelen adat.

\section{Irodalom}

Bence Erika. 2012. Asztaltársaság és hírlap. In Arachné szőnyege: A magyar irodalom alakulástörténeti , szövevénye” a XVIII. század végétől napjainkig. 53-60. Újvidék: Bölcsészettudományi Kar-Vajdasági Magyar Felsőoktatási Kollégium.

Bence Erika. 2015. Az első világháború tematizációja az 1930-as évek vajdasági magyar irodalmában. In Virtuális irodalomtörténet. 102-113. Veszprém: Iskolakultúra.

Bence Erika. 2015a. „Sci-fi”” a háborúban (Tarkó János: Amíg a nagy vihar tombolt). Hungarológiai Közlemények 46 (2): 51-65.

Bence Erika. 2017. Egy legionista a háborúban. Szabó István-Andrée Dezső: Egy legionista naplója. Hat esztendő a Francia Idegenlégióban (1923-1929). Tanulmányok 50 (1): 118-139. In Miért sír Szulimán?: Elemzések, bírálatok a magyar irodalom köréböl. 117-145. Budapest: Cédrus Mủvészeti Alapítvány-Napkút Kiadó.

Bence Erika. 2017a. Napló(regény) az első világháborúból. Darvas Gábor: „Mindent meggondoltam és mindent megfontoltam..." Hungarológiai Közlemények 45 (3): 106-117. In Miért sir Szulimán?: Elemzések, birálatok a magyar irodalom köréböl. 103-117. Budapest: Cédrus Mủvészeti Alapítvány-Napkút Kiadó.

Bence Erika. 2018. Vajdasági magyar irodalmi lexikon (1918-2014). Gerold László: Vajdasági magyar irodalmi lexikon (1918-2014). In NapútOnline. Január. http:// www.naputonline.hu/2018/01/07/bence-erika-vajdasági-magyar-irodalmilexikon-1918-2014/ (2020. aug. 4.)

Bence Erika. 2018a. Magyar bestsellerek, irodalmi (világ)sikerek a két világháború között. Hungarológiai Közlemények 49 (2): 34-55. In Utazások Posztmonarchiában: Kulturális kontextusok. Elemzések, bírálatok a magyar irodalom köréböl. 45-61. Szabadka: Életjel. 
Bence Erika-Kocsis Lenke. 2019. Memoires, Diaries, Diary Novels about the First World War in Haungarian Literature. Stredoeurópske pohl'ady 1 (1): 86-94.

Bence Erika-Ispánovics Csapó Julianna. 2020. Kuncz Aladár Fekete kolostor címü regénye az első világháborút tematizáló regények sorában. Kézirat.

Bori Imre. 1968. A jugoszláviai magyar irodalom története 1918-1945. Újvidék: Forum Könyvkiadó.

Bori Imre. 1975. Irodalmunk évszázadai. Újvidék: Forum Könyvkiadó.

Bori Imre. 2007. A jugoszláviai magyar irodalom története. Gerold László: Bori Imre (349-352). Szerk., jegyz.: B.[ordás] Gy.[őző] (399-340). Újvidék: Forum Könyvkiadó (5. kiadás).

Csáky S. Piroska. 1988. Vajdasági magyar könyvek 1918-1941. Újvidék: Forum Könyvkiadó.

Faragó Kornélia. 2004. A kezdet-kultusz közösségi térideje. Hungarológiai Közlemények 35 (1): 78-89.

Gerold László. 2001. Jugoszláviai magyar irodalmi lexikon (1918-2000). Újvidék: Forum Könyvkiadó.

Gerold László. 2016. Vajdasági magyar irodalmi lexikon (1918-2014). Újvidék: Forum Könyvkiadó.

Hajdu Péter. 2001. Történetek metaforikus interakciója. Mikszáth Kálmán: Galamb a kalitkában. In Romantika, világkép, müvészet, irodalom, szerk. Szegedy-Maszák Mihály-Hajdu Péter. 219-242. Budapest: Osiris.

Ispánovics Csapó Julianna. 2009. A jugoszláviai magyar irodalom 2000-2001. évi bibliográfi ja. Bibliográfiai füzetek 34-35. 273. Úvidék: Bölcsészettudományi Kar, 5083. tétel.

Ispánovics Csapó Julianna. 2011. A bácskai magyar irodalmi kultúra elötörténete a régió magyar könyvkiadása szempontjából. Újvidék: Filozofski fakultet u Novom Sadu.

Kuncz Aladár. 1931. Fekete kolostor: Feljegyzések a francia internáltságból. Kolozsvár: Erdélyi Szépmíves Céh.

Márton László. 1998. A kitaposott zsákutca, avagy a történelem a történetekben (Két példa). Jelenkor 41 (2): 146-169.

Németh Ferenc. 2001. Egy tanító bevonul az irodalomba. A vajdasági magyar irodalom első kötetéröl. Magyar Szó, Kilátó, jan. 20. 13.

Németh Ferenc. 2014. A Nagy Háború (ismeretlen) regénye. Tarkó János: Amíg a nagy vihar tombolt... Tanulmányok 48 (1): 100-109.

Németh Ferenc. 2018. 1919: A kisebbségi irodalmi öneszmélés éve Nagybecskereken: Adalék a vajdasági magyar irodalom kezdeteihez. Hungarológiai Közlemények 49 (3): 128-135. 
Rózsafalvi Zsuzsanna. 1998. A szövegköziség a Mikszáth-poétikában. In Eisemann György szerk. A kánon peremén: Az irodalmi modernség alakváltozatai a XIX-XX. század fordulójának magyar prózájában. 137-150. Budapest: ELTE, XVIII-XIX. századi Magyar Irodalomtörténeti Tanszék.

Tarkó János. 1919. Amíg a nagy vihar tombolt... Nagybecskerek: Haász Testvérek.

\section{WHAT HAPPENED IN HUNGARIAN LITERATURE IN YUGOSLAVIA/VOJVODINA IN 1918?}

The research examines one of the most important principles of the Hungarian literary history discourse in Vojvodina - considered valid to this day - the axiom formed at the beginning of 1918. The interpretation and understanding of the results take into account the ideological influen es, historical-poetic traditions and literary approaches that led to and influenced the above-mentioned canonization procedures (synthesis of Hungarian literary history in Vojvodina, creating the Lexicon of Hungarian Literature in Yugoslavia then in Vojvodina, publishing book histories and bibliographies) the beginnings of Hungarian literature in Yugoslavia / Vojvodina were connected with the date of the establishment of a political construct, the Kingdom of Serbs, Croats and Slovenes. The paper presents the sense in which modern perceptions of the history of literature have overturned the positivist and substantive methods that defined the mentioned historical ideas, thus modifying / deconstructing the overall picture of the life form of Hungarian literature in Yugoslavia / Vojvodina. At the same time, the interpretation preserves the canonical, forward-looking and enduring values of historical traditions (e.g. Imre Bori's vision of literary history).

Keywords: 1918, Hungarian literature in Yugoslavia/Vojvodina; Kingdom of Serbs, Croats and Slovenes; Szenteleky cult, János Tarkó

\section{ŠTA SE DOGODILO U MAĐARSKOJ KNJIŽEVNOSTI U JUGOSLAVIJI/VOJVODINI 1918. GODINE?}

Istraživanje se bavi jednim od najvažnijih načela mađarskog književnoistorijskog diskursa u Vojvodini koje se do danas smatralo opšteprihvaćenim aksiomom, formiranim s početka 1918. Predstavljanje i interpretacija rezultata u radu uzimaju u obzir ideološke uticaje, istorijsko-poetske tradicije i književne pristupe koji su doveli i uticali na gorepomenute postupke kanonizacije (sinteza vojvođanske mađarske književne istorije, stvaranje jugoslovenskog a potom i vojvođanskog mađarskog književnog leksikona, izdavanje bibliografi a i književnih istorija), čime se počeci mađarske književnosti u Jugoslaviji, tj. Vojvodini povezuju sa datumom uspostavljanja jednog političkog konstrukta, Kraljevine SHS. Savremene percepcije istorije književnosti preokrenule su pozitivističke i sadržajne metode koje 
su definisale pomenute istorijske ideje, modifikuj ći/dekonstruišući celokupnu sliku života mađarske književnosti u Jugoslaviji, tj. Vojvodini. S druge strane, u radu su sačuvane kanonske, perspektivne i trajne vrednosti istorijskih tradicija, npr. vizija istorije književnosti Imrea Borija.

Ključne reči: 1918, jugoslovenska mađarska književnost, vojvođanska mađarska književnost, Kraljevina SHS, Sentelekijev kult, Janoš Tarko 